\title{
Protective Activity of Beetroot Extract on Doxorubicin-Induced Hepatic and Renal Toxicity in Rat Model
}

\author{
Sony Eka Nugraha ${ }^{1 *}$ D, Yuandani Yuandani ${ }^{2}$ D, Rony Abdi Syahputra ${ }^{2}$ (D) \\ ${ }^{1}$ Department of Pharmaceutical Biology, Faculty of Pharmacy, Universitas Sumatera Utara, Medan, Indonesia; ${ }^{2}$ Department of \\ Pharmacology, Faculty of Pharmacy, Universitas Sumatera Utara, Medan, Indonesia
}

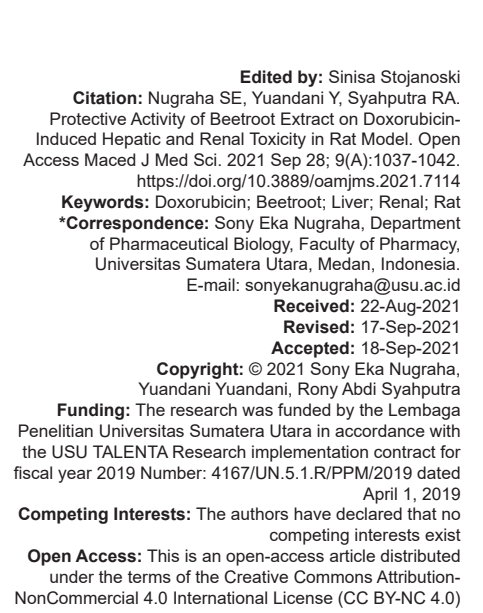

Introduction

The anticancer that is widely used as common therapy in cancer is doxorubicin. It is an anthracycline group that is isolated from Streptomyces peucetius var caesius [1]. The conditions of oxidative stress are closely related to doxorubicin therapy which is characterized by the formation of lipid peroxidation which has the potential to cause cell damage [2]. Doxorubicin toxicity can cause degeneration of organs such as the heart, kidneys, liver, and brain [3]. The chemical structure of doxorubicin has the potential to form free radicals through various mechanisms. Quinone groups in the tetracyclic ring of doxorubicin can release several superoxide radicals [4]. Doxorubicin metabolism also causes the formation of reactive aglycone metabolites and alcohol metabolites which can disturb the balance of iron intracellular concentrations [5]. The administration of doxorubicin can increase the production of reactive oxygen species (ROS) and disrupt the balance of antioxidant defenses so that it triggers a cell damage [6]. ROS are normally produced by the body in the process of metabolism, to overcome them, the body has a defense system against ROS by producing antioxidant enzymes such as the enzyme of superoxide dismutase, catalase, glutathione and others so as not to trigger oxidative damage [7]. Excessive free radical production and reduced antioxidant defense system will cause cell damage. There have been many studies that proved the toxicity of doxorubicin to organs especially the heart, kidneys, and liver. The liver, as an organ that plays a role in metabolism, is one of the organs that have the potential to be damaged by the administration of doxorubicin. In addition, the kidneys will experience the same event due to high stress oxidative conditions. Several studies have shown that doxorubicin-induced liver and kidney damage by inflammatory processes, free radicals, oxidative stress, and lipid peroxidation [8], [9], [10]. To prevent the toxicity of doxorubicin to several body organs, it is necessary to have antioxidant supplementation to ward off free radicals from doxorubicin. One of the plants that have high antioxidant is beet tuber (Beta vulgaris $L$ ). Beetroot contains phytochemical constituents in the form of tannins, saponins, alkaloids, flavonoids, terpenoids, and steroids as well as content of betacyanins which have antioxidant effects [11]. Due to its phytochemical constituent, beetroot has a potential effect as protective agent in inhibiting the radical process of ROS. Based 
on the description mentioned, this study was aimed to investigate the preventive effects of beetroot ethanol extract ( $B$. vulgaris L.) in doxorubicin-induced liver and renal toxicity in rat.

\section{Materials and Methods}

\section{Tools and materials}

Rotary evaporator, whatmann filter paper no. 42, analytical balance (Boeco), light microscope (Boeco), distilled water, chloroform, beetroot, male white rats, ethanol 96\% (Merck), CMC-Na (Bratachem), and doxorubicin (Kalbe).

\section{Plant collection and extraction of beetroot}

Beetroot tuber was collected from local market at Padang Bulan, North Sumatera, Indonesia. An amount of $300 \mathrm{~g}$ dried beetroot were crushed then macerated in ethanol $96 \%$ for 5 days. The products were evaporated with a rotary evaporator at a temperature of $\pm 50^{\circ} \mathrm{C}$, then dried on a water bath [12].

\section{Identification of phytochemical contents}

Phytochemical screening carried out on ethanol extract beetroot included examining the secondary chemical metabolites of alkaloids, flavonoids, glycosides, tannins, saponins, terpenoids, and steroids [13], [14].

\section{Animals and blood samples}

Animals used in this study were 25 male Wistar rats, weighing 180-220 g. The blood samples were collected from inferior vein cava.

\section{Experimental design}

Rats were divided into 25 groups and each group consisted of 5 namely:

a. Normal control: Normal tested groups without treatment

b. Negative control: Group induced by accumulative dose of doxorubicin $15 \mathrm{mg} / \mathrm{kg}$ body weight $(\mathrm{BW})+\mathrm{Na}-\mathrm{CMC}$ suspension

c. Dose 100: Treated group that induced by accumulative dose of doxorubicin $15 \mathrm{mg} / \mathrm{kg}$ $\mathrm{BW}+$ extract dose of $100 \mathrm{mg} / \mathrm{kgBW}$

d. Dose 200: Treated group that induced by accumulative dose of doxorubicin $15 \mathrm{mg} / \mathrm{kg}$ BW + extract dose of $200 \mathrm{mg} / \mathrm{kg} \mathrm{BW}$

e. Dose 400: Treated group that induced by accumulative dose of doxorubicin $15 \mathrm{mg} / \mathrm{kg}$ $\mathrm{BW}+$ extract dose of $400 \mathrm{mg} / \mathrm{kg} \mathrm{BW}$.
Rats were induced using doxorubicin injection for 15 days with an accumulative dose of $15 \mathrm{mg} / \mathrm{kg} \mathrm{BW}$ intraperitonially, and the extract was given together during the 15 days doxorubicin range. On day $16^{\text {th }}$, the animals were anesthetized with chloroform, blood samples were collected then estimated the level of alanine aminotransferase (ALT), aspartate aminotransferase (AST), Creatinine and blood urea nitrogen (BUN).

\section{Histological analysis}

Microscopic examination on tissue section was conducted by slicing with a microtome after the liver and kidney have been embedded in paraffin with hematoxylin and eosin [15]. Observation was performed using a light microscope.

\section{Statistical analysis}

Statistical analysis was performed using analysis of variance withTukey's Multiple Comparison Test. p-value for significance was set at 0.05 . Values for all measurements were expressed as the mean \pm SD.

\section{Results and Discussion}

\section{Phytochemical screening result of ethanol extract beetroot}

The ethanol extract of beetroot contained of flavonoids, alkaloids, saponins, tannins, glycosides and steroids/terpenoid.

\section{Effect of beetroot ethanol extract on ALT}

In this research, ALT levels were examined from rats blood. The results of the levels obtained are presented in Table 1.

Table 1: Effect of Beetroot Extract (BE) Treatment on ALT level (U/L)

\begin{tabular}{lllllll}
\hline Group & ALT level (U/L) & & & Mean ALT \pm SD (U/L) \\
\hline Normal Control & 172.9 & 167.6 & 164.5 & 188.1 & 179.8 & $174.58 \pm 9.52^{*}$ \\
Negative Control & 453.8 & 423.3 & 429.8 & 488.3 & 412.9 & $441.62 \pm 30.11$ \\
BE $100 \mathrm{mg} / \mathrm{kg} \mathrm{BW}$ & 399.7 & 385 & 390.3 & 389.8 & 354.2 & $383.8 \pm 17.38$ \\
BE $200 \mathrm{mg} / \mathrm{kg} \mathrm{BW}$ & 337.3 & 296.2 & 331.2 & 286.7 & 290.1 & $308.3 \pm 24.02^{*}$ \\
BE 400 m/kg BW & 247.2 & 234.1 & 241.7 & 257.9 & 248.6 & $245.9 \pm 8.80^{*}$ \\
\hline Data expressed as mean \pm SD $(\mathrm{n}=5)$, ${ }^{*}$ significant difference versus negative control group at $\mathrm{P}<0.01$. BW:
\end{tabular}
Body weight, ALT: Alanine aminotransferase.

The negative control group (doxorubicin only) had an average ALT level of $441.62 \pm 30.11 \mathrm{U} / \mathrm{L}$. The treatment group at a dose of $100 \mathrm{mg} / \mathrm{kg} \mathrm{BW}$ had an ALT level of $383.8 \pm 17.38 \mathrm{U} / \mathrm{L}$. The treatment group at a dose of $200 \mathrm{mg} / \mathrm{g} \mathrm{BW}$ had an ALT value of $308.3 \pm 24.02$ $\mathrm{U} / \mathrm{L}$. The treatment group at a dose of $400 \mathrm{mg} / \mathrm{kg} \mathrm{BW}$ had an ALT value of $245.9 \pm 8.80 \mathrm{U} / \mathrm{L}$. The mean value of $A L T$ in the beetroot ethanol extract treatment group at 
dose of $200 \mathrm{mg} / \mathrm{kg} \mathrm{BW}$ was significantly different from negative control $(p<0.05$; Table 1$)$.

\section{Effect of beetroot extract (BE) treatment on AST level}

In this research, AST levels of rats blood were examined. The results of the levels obtained are presented in Table 2.

Table 2: Effects of BE treatment on AST Level

\begin{tabular}{lllllll}
\hline Group & AST level (U/L) & & & & Mean \pm SD $(\mathrm{U} / \mathrm{L})$ \\
\hline Normal control & 65.3 & 70.2 & 64.5 & 51.5 & 57.2 & $61.74 \pm 7.37^{*}$ \\
Negative control & 145.4 & 165.2 & 134 & 155.3 & 158.2 & $151.62 \pm 12.14$ \\
$\mathrm{BE} 100 \mathrm{mg} / \mathrm{kg} \mathrm{BW}$ & 124.3 & 118.7 & 110.2 & 109.6 & 124 & $117.36 \pm 7.16^{*}$ \\
$\mathrm{BE} 200 \mathrm{mg} / \mathrm{kg} \mathrm{BW}$ & 93.6 & 93.3 & 87 & 92.8 & 79.4 & $89.22 \pm 6.12^{*}$ \\
$\mathrm{BE} 400 \mathrm{mg} / \mathrm{kg}$ BW & 82.1 & 83.8 & 76.3 & 69.2 & 88.4 & $79.96 \pm 7.41^{*}$ \\
\hline Data expressed as mean $\pm \mathrm{SD}(\mathrm{n}=5),{ }^{*}$ significant difference versus negative control group at $\mathrm{P}<0.01 . \mathrm{BE}:$ \\
Beetroot extract, BW: Body weight.
\end{tabular}

The negative control group (doxorubicin only) had an average AST value of $151.62 \pm 12.14 \mathrm{U} / \mathrm{L}$. The treatment group dose $100 \mathrm{mg} / \mathrm{kg}$ BW had AST values of $117.36 \pm 7.16 \mathrm{U} / \mathrm{L}$. The treatment group with a dose of $200 \mathrm{mg} / \mathrm{kg} \mathrm{BW}$ had an AST value of $89.22 \pm 6.12 \mathrm{U} / \mathrm{L}$. The treatment group at a dose of $400 \mathrm{mg} / \mathrm{kg}$ BW had an AST value of $79.96 \pm 7.41 \mathrm{U} / \mathrm{L}$. Based on (Table 2), it was known that the mean AST value in the beetroot ethanol extract treatment group with a dose of $100 \mathrm{mg} /$ $\mathrm{kgBW}$ was significantly different from the negative control $(p<0.05$; Table 2).

\section{Effect of beetroot ethanol extract on creatinine levels}

In this research, creatinine levels from rats blood were examined. The results of the levels obtained are presented in Table 3.

Table 3: Effect of Beetroot Ethanol Extract on creatinine levels

\begin{tabular}{lllllll}
\hline Group & \multicolumn{7}{l}{ Creatinine levels $(\mathrm{mg} / \mathrm{dl})$} & & & Mean $\pm \mathrm{SD}(\mathrm{mg} / \mathrm{dl})$ \\
\hline Normal Control & 0.23 & 0.27 & 0.28 & 0.25 & 0.24 & $0.26 \pm 0.01^{*}$ \\
Negative Control & 0.45 & 0.49 & 0.45 & 0.45 & 0.48 & $0.46 \pm 0.01$ \\
$\mathrm{BE} 100 \mathrm{mg} / \mathrm{kg} \mathrm{BW}$ & 0.38 & 0.45 & 0.47 & 0.43 & 0.45 & $0.43 \pm 0.03$ \\
$\mathrm{BE} 200 \mathrm{mg} / \mathrm{kg} \mathrm{BW}$ & 0.34 & 0.38 & 0.37 & 0.36 & 0.39 & $0.34 \pm 0.01^{*}$ \\
$\mathrm{BE} 400 \mathrm{mg} / \mathrm{kg}$ BW & 0.36 & 0.29 & 0.27 & 0.30 & 0.30 & $0.25 \pm 0.01^{*}$ \\
\hline Data expressed as mean \pm SD $(\mathrm{n}=5)$ *significant difference vs. negative control group at $P<0.01$. \\
BE: Beetroot extract, BW: Body weight.
\end{tabular}

The negative control group (doxorubicin only) had an average creatinine value of $0.46 \pm 0.01 \mathrm{mg} / \mathrm{dl}$. The treatment group dose $100 \mathrm{mg} / \mathrm{kg}$ BW has creatinine value of $0.43 \pm 0.03 \mathrm{mg} / \mathrm{dl}$. The treatment group at dose of $200 \mathrm{mg} / \mathrm{kg} \mathrm{BW}$ has a creatinine value of $0.34 \pm$ $0.01 \mathrm{mg} / \mathrm{dl}$. The treatment group at a dose of $400 \mathrm{mg} / \mathrm{kg}$ BW has a creatinine value of $0.25 \pm 0.01 \mathrm{mg} / \mathrm{dl}$. Based on the table, it was known that the mean creatinine value in the beetroot ethanol extract treatment group with a dose of $200 \mathrm{mg} / \mathrm{kg} \mathrm{BW}$ was significantly different from negative controls $(p<0.05$; Table 3$)$.

\section{Effect of beetroot ethanol extract on urea}

In this research, urea levels were examined in the blood of rats. The results obtained were presented in Table 4.
The negative control group (doxorubicin only) had an average urea value of $55.4 \pm 1.74 \mathrm{mg} / \mathrm{dl}$. The treatment group at dose of $100 \mathrm{mg} / \mathrm{kg} \mathrm{BW}$ had mean blood urea level of $48 \pm 1.41 \mathrm{mg} / \mathrm{dl}$. The treatment group with a dose of $200 \mathrm{mg} / \mathrm{kg}$ BW had mean blood urea level of $45.2 \pm 0.97 \mathrm{mg} / \mathrm{dl}$. The treatment group at dose of $400 \mathrm{mg} / \mathrm{kg}$ BW had mean blood urea level of $40.6 \pm 2.15 \mathrm{mg} / \mathrm{dl}$. Therefore, the average urea in the treatment group of beetroot ethanol extract at a dose of $200 \mathrm{mg} / \mathrm{kg} \mathrm{BW}$ was significantly different from negative controls $(p<0.05$; Table 4).

Table 4: Effects of beetroot ethanol extract on urea level

\begin{tabular}{lllllll}
\hline Groups & \multicolumn{7}{l}{ Urea level $(\mathrm{mg} / \mathrm{dl})$} & & & Mean \pm SD $(\mathrm{mg} / \mathrm{dl})$ \\
\hline Normal control & 43 & 41 & 41 & 43 & 39 & $41.4 \pm 1.49^{*}$ \\
Negative control & 53 & 56 & 58 & 54 & 56 & $55.4 \pm 1.74$ \\
BE at dose of $100 \mathrm{mg} / \mathrm{kg} \mathrm{BW}$ & 46 & 48 & 50 & 49 & 47 & $48 \pm 1.41^{*}$ \\
BE at dose of $200 \mathrm{mg} / \mathrm{kg} \mathrm{BW}$ & 47 & 45 & 45 & 44 & 45 & $45.2 \pm 0.97^{*}$ \\
BE at dose of $400 \mathrm{mg} / \mathrm{kg} \mathrm{BW}$ & 38 & 42 & 43 & 42 & 38 & $40.6 \pm 2.15^{*}$ \\
\hline \multicolumn{7}{l}{ Data expressed as mean $\pm \mathrm{SD}(\mathrm{n}=5)}$. \\
\hline
\end{tabular}

Data expressed as mean \pm SD $(n=$ Beetroot extract, BW: Body weight.

\section{Histological assessment}

Figures 1 and 2 showed necrotic cells after treatment by large dose of doxorubicin. Microscopic examination on kidney and hepatic tissues showed no necrosis after treatment by beetroot extract at dose of 200 and $400 \mathrm{mg} / \mathrm{kg} \mathrm{BW}$. The result was in agreement with the biochemistry examinations, that the beetroot extract prevented necrosis in hepatic and kidney cells. The polyphenol content in beetroot might play important role in inhibiting hepatic and kidney necrosis induced by doxorubicin.

Elevation of oxidative stress by doxorubicin causes mitochondrial damage, lipid oxidation, and causes cell damage [16]. Cell damage can have an impact on degradation of organs such as liver and kidney tissues. It can increase liver function biomarkers ALT and AST as well as an increase in creatinine and BUN levels as markers of kidney function. This indicates that the induction of doxorubicin affects organs functions in the body. Table 5 showed that the group treated with beetroot extract at a dose of $200 \mathrm{mg} /$ kg BW could improve serum levels of ALT and AST compared with negative controls $(p<0.05)$. The group treated with beetroot extract at a dose of $100 \mathrm{mg} / \mathrm{kg}$ BW also showed an improved effect on creatinine and urea values of rats compared with negative controls $(p<0.05)$. All parameters showed dose-dependent effect in the protective activity of beetroot extract on doxorubicin-induced toxicity.

Many studies had reported the role of medicinal plant in inhibiting hepatotoxic and nephrotoxic effects [17], [18], [19], [20]. The antioxidant content in beetroot extract activity might play a role in hepatoprotective and nephroprotective effects by inhibiting ROS. Beetroot contains marker compounds namely betanin which is a red pigment in beetroot [21], some phytochemical compound also found in beet root such as tannins, saponins, alkaloids, flavonoids, terpenoids and steroids. Betanin has an 


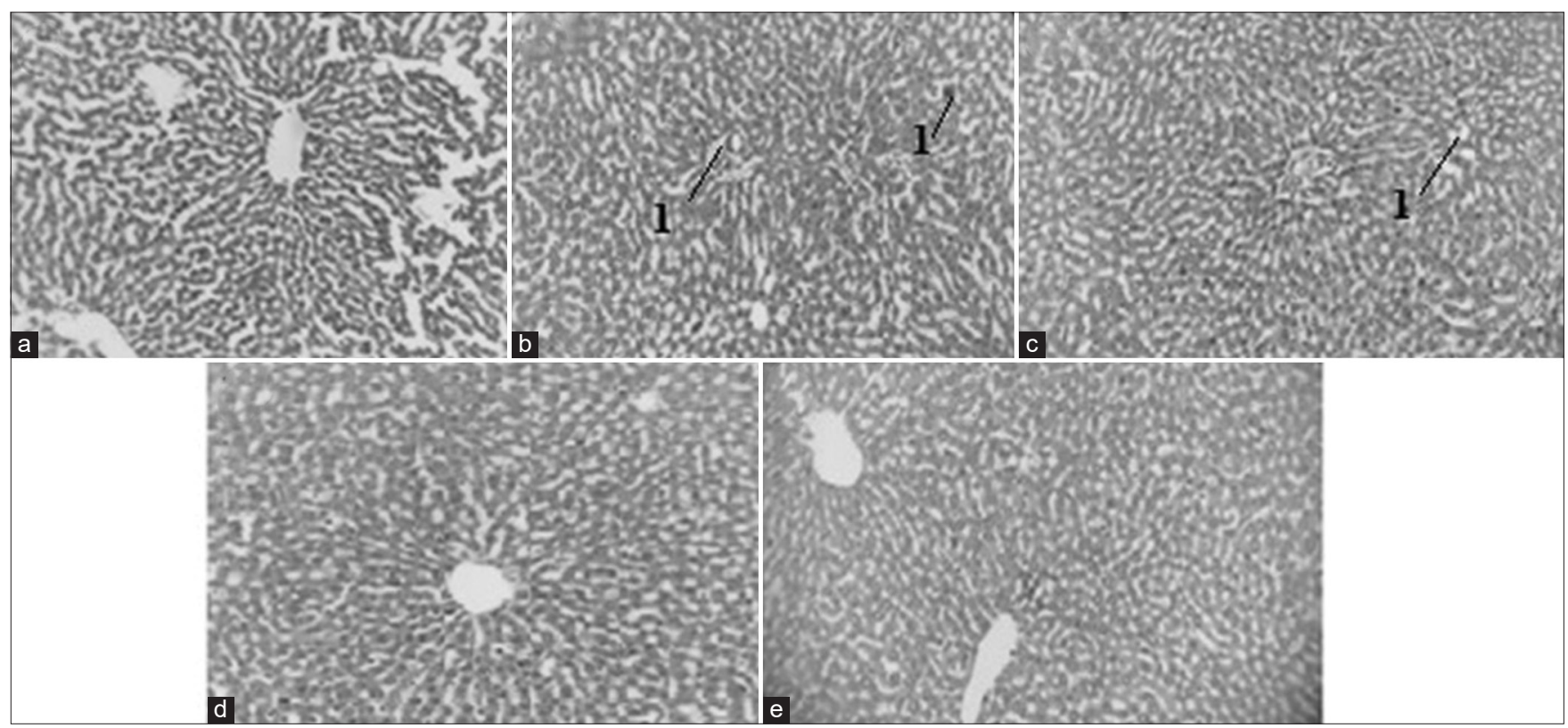

Figure 1: Microscopic examination $(10 \times 10)$ of (a) liver of normal control rat; (b) liver of negative control rat; (c) liver after treatment with beetroot extract at $100 \mathrm{mg} / \mathrm{kg}$ body weight (BW); (d) liver after treatment with beetroot extract at $200 \mathrm{mg} / \mathrm{kg}$ BW; (e) liver after treatment with beetroot extract at $400 \mathrm{mg} / \mathrm{kg} B W$; (1) necrotic hepatocytes

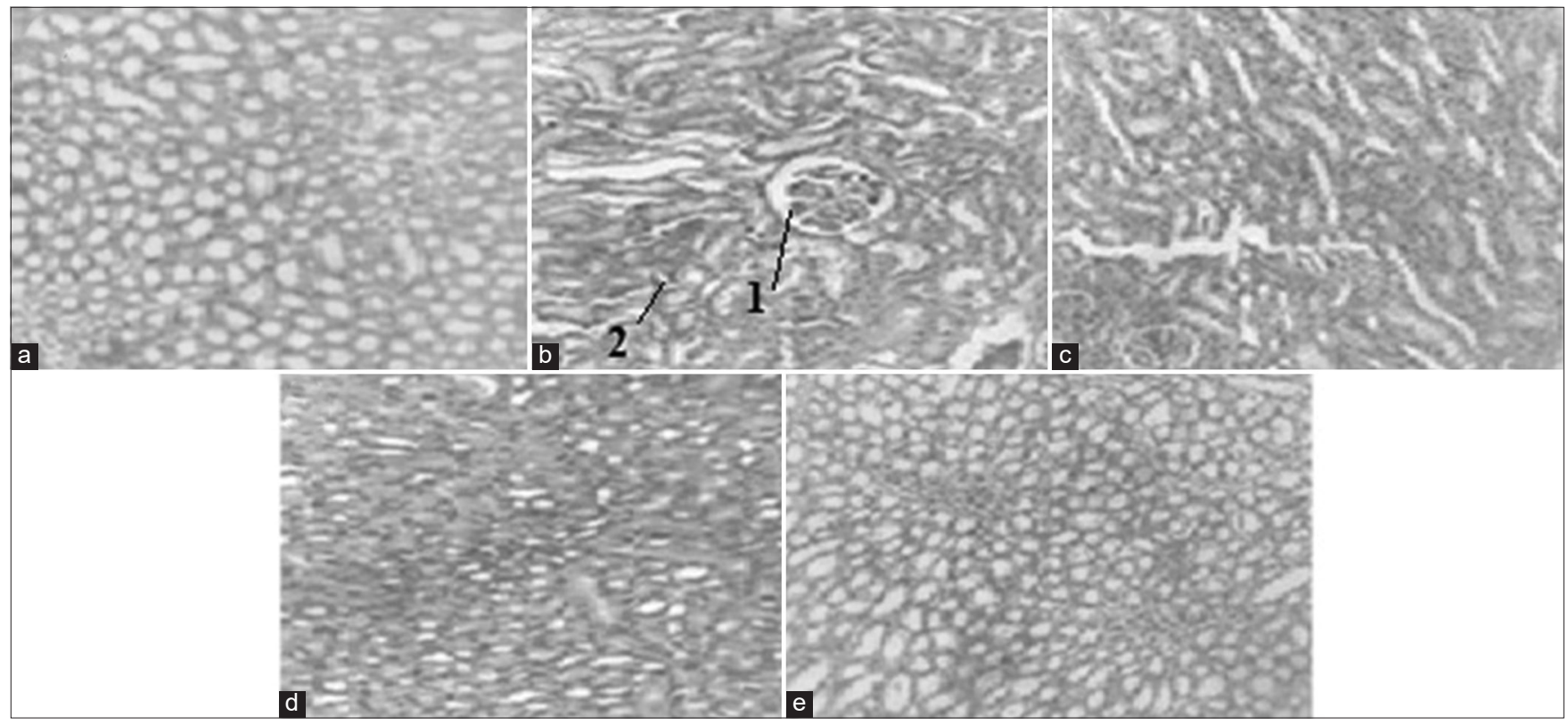

Figure 2: Microscopic examination $(10 \times 10)$ of (a) Kidney of normal control rat; (b) Kidney of negative control rat (c) Kidney after treatment with beetroot extract at $100 \mathrm{mg} / \mathrm{kg}$ body weight (BW); (d) Kidney after treatment with beetroot extract at $200 \mathrm{mg} / \mathrm{kg}$ BW; (e) Kidney after treatment with beetroot extract at $400 \mathrm{mg} / \mathrm{kg} B W$; (1) Glomerulus atrophy; (2) Necrotic

antioxidant activity [22]. Betanin is a red-violet pigment that is a heterocyclic compound found in beetroot (B. vulgaris L.) [23], [24]. The antioxidant activity of betanin is due to the presence of a hydroxyl and cyclic amine groups that are hydrogen and electron donors, it has an efficacy to stabilize the reactive species [25]. In addition, phytochemical contents in beetroot were a powerful antioxidant that can prevent ROS free radical reactions caused by doxorubicin.

The antioxidant compounds present in beetroot in the form of betanin and also the content of flavonoids and tannins which are polyphenols play roles in protecting liver and kidney against oxidative stress induced by doxorubicin. These results were also in line with research conducted by El Gamal et al. (2014), and Agarwal et al. (2006) who concluded that beetroot extract protects the kidney function of mice in gentamicininduced nephrotoxicity and it also can protect the liver function of mice induced by $\mathrm{CCl} 4$ [26], [27]. Based on histological analysis, supplementation of beetroot extracts which are rich in antioxidants can provide protection against oxidative stress reactions caused by doxorubicin. 


\section{Conclusion}

Beetroot ethanol extract has hepatoprotective and nephroprotective activities in rats that are induced by doxorubicin and it showed dose- dependent effects.

\section{Acknowledgment}

The authors express their profound gratitude and appreciations to the Faculty of Pharmacy Universitas Sumatera Utara for supporting this research.

\section{References}

1. Hillerdal G, Brodin O, Hjerpe A, Sorensen JB, Sundström S. Malignant pleural mesothelioma: Treatment with liposomizeddoxorubicine. A phase two Scandinavian study. Eur J Cancer. 2001;37:S44. http://dx.doi.org/10.1016/ s0959-8049(01)80642-0

2. Barrera G. Oxidative stress and lipid peroxidation products in cancer progression and therapy. ISRN Oncol. 2012;2012:137289. http://dx.doi.org/10.5402/2012/137289 PMid:23119185

3. Ilie M, Margin D. Trends in the evaluation of lipid peroxidation processes. Lipid Peroxidation. London: IntechOpen; 2012. http://dx.doi.org/10.5772/46075

4. Suresh A, Guedez L, Moreb J, Zucali J. Overexpression of manganese superoxide dismutase promotes survival in cell lines after doxorubicin treatment. $\mathrm{Br} \mathrm{J}$ Haematol. 2003;120(3):45763. http://dx.doi.org/10.1046/j.1365-2141.2003.04074.x PMid:12580960

5. Wu X, Hasinoff BB. The antitumor anthracyclines doxorubicin and daunorubicin do not inhibit cell growth through the formation of iron-mediated reactive oxygen species. Anticancer Drugs. 2005;16(1):93-9. http://dx.doi. org/10.1097/00001813-200501000-00014

PMid:15613911

6. Chakraborty A, Gupta N, Ghosh K, Roy P. In vitro evaluation of the cytotoxic, anti-proliferative and anti-oxidant properties of pterostilbene isolated from Pterocarpus marsupium. Toxico In Vitro. 2010;24(4):1215-28. http://dx.doi.org/10.1016/j. tiv.2010.02.007

PMid:20152895

7. Dizdaroglu $M$, Jaruga $P$. Mechanisms of free radical-induced damage to DNA. Free Radic Res. 2012;46(4):382-419. http:// dx.doi.org/10.3109/10715762.2011.653969 PMid:22276778

8. Afsar T, Razak S, Almajwal A, Al-Disi D. Doxorubicin-induced alterations in kidney functioning, oxidative stress, DNA damage, and renal tissue morphology; Improvement by Acacia hydaspica tannin-rich ethyl acetate fraction. Saudi J Biol Sci. 2020;27(9):2251-60. http://dx.doi.org/10.1016/j. sjbs.2020.07.011

PMid:32884406
9. Saleem F, Hashmi F, Saleem Z, Ahmad M, Saeed H, Aziz $\mathrm{M}$, et al. Comparative study of changes in renal and electrolyte profiles induced by liposomal doxorubicin versus conventional doxorubicin-based regimens in cancer patients. J Pharm Bioallied Sci. 2016;2016:186322. http://dx.doi. org/10.4103/0975-7406.186322

10. Price KE, Larive CK, Lunte CE. Tissue-targeted metabonomics: Biological considerations and application to doxorubicininduced hepatic oxidative stress. Metabolomics. 2008;5(2):21928. http://dx.doi.org/10.1007/s11306-008-0141-3

11. Wruss J, Waldenberger $G$, Huemer $S$, Uygun $P$, Lanzerstorfer $P$, Müller $\mathrm{U}$, et al. Compositional characteristics of commercial beetroot products and beetroot juice prepared from seven beetroot varieties grown in Upper Austria. J Food Compos Anal. 2015;42:46-55. http://dx.doi.org/10.1016/j.jfca.2015.03.005

12. Depkes RI. Materia Medika. $6^{\text {th }}$ ed. Jakarta: Ditjen POM; 1995. p. 297-307.

13. Cordell GA, Quinn-Beattie ML, Farnsworth NR. The potential of alkaloids in drug discovery. Phytother Res. 2001;15(3):183-205. http://dx.doi.org/10.1002/ptr.890 PMid:11351353

14. Owoeye TF, Ajani OO, Akinlabu DK, Ayanda OI, Ajani OO Proximate composition, structural characterization and phytochemical screening of the seed oil of Adenanthera pavonina linn. Rasayan J Chem. 2017;10(3):807-14. http:// dx.doi.org/10.7324/rjc.2017.1031687

15. Gamble M. The Hematoxylins and Eosin. Theory and Practice of Histological Techniques. Amsterdam, Netherlands: Elsevier; 2008. p. 121-34. http://dx.doi.org/10.1016/ b978-0-443-10279-0.50016-6

16. Zhou S, Palmeira CM, Wallace KB. Doxorubicin-induced persistent oxidative stress to cardiac myocytes. Toxicol Lett. 2001;121(3):151-7. http://dx.doi.org/10.1016/ s0378-4274(01)00329-0

PMid:11369469

17. Yuandani, Mardaliza S, Marianne. Hepatoprotective activity of Curcuma mangga extract on paracetamol-induced male mice. Indones J Pharm Clin Res. 2018;1(2):35-40. http://dx.doi. org/10.32734/idjpcr.v1i2.432

18. Rosita R, Yuandani Y, Marianne M. Nephroprotective activity of ethanol extract of Curcuma mangga Val. in paracetamolinduced male mice. Asian J Pharm Clin Res. 2018;1(13):126. http://dx.doi.org/10.22159/ajpcr.2018.v11s1.26585

19. Ramadhiani AR, Harahap U, Dalmunthe A. Nephroprotective activity of ethanol extract root of cogon grass (Imperata cylindrica L. (Beauv.)) on creatinine, urea levels, and hematology profile against gentamycin-induced renal toxicity in rats. Asian J Pharm Clin Res. 2018;11(13):97. http://dx.doi.org/10.22159/ajpcr.2018. v11s1.26578

20. Nerdy N, Ritarwan K. Hepatoprotective activity and nephroprotective activity of peel extract from three varieties of the passion fruit (Passiflora Sp.) in the albino rat. Open Access Maced J Med Sci. 2019;7(4):536-42. http://dx.doi.org/10.3889/ oamjms.2019.153

21. Saber A, Abedimanesh N, Somi MH, Khosroushahi AY Anticancer Effects of Beetroot Hydro-Alcoholic Extract and Betanin on Human Colorectal Cancer Cell Lines. Research Square; 2020. http://dx.doi.org/10.21203/rs.3.rs-90862/v1

22. da Silva DV, dos Santos Baião D, de Oliveira Silva F, Alves G, Perrone D, Mere Del Aguila E, et al. Betanin, a natural food additive: Stability, bioavailability, antioxidant and preservative ability assessments. Molecules. 2019;24(3):458. http://dx.doi. org/10.3390/molecules24030458 PMid:30696032

23. Rodriguez-Amaya DB. Natural Food Pigments and Colorants. Reference Series in Phytochemistry. Berlin/Heidelberg, 
Germany: Springer International Publishing; 2019. p. 867-901. http://dx.doi.org/10.1007/978-3-319-78030-6_12

24. Račkauskienè I, Pukalskas A, Venskutonis PR, Fiore A, Troise AD, Fogliano V. Effects of beetroot (Beta vulgaris) preparations on the Maillard reaction products in milk and meatprotein model systems. Food Res Int. 2015;70:31-9. http:// dx.doi.org/10.1016/j.foodres.2015.01.026

25. Al-Numair KS, Chandramohan G, Alsaif MA. Pretreatment with morin, a flavonoid, ameliorates adenosine triphosphatases and glycoproteins in isoproterenol-induced myocardial infarction in rats. J Nat Med. 2011;66(1):95-101. http://dx.doi.org/10.1007/ s11418-011-0558-2

PMid:21698512
26. El Gamal AA, AISaid MS, Raish M, Al-Sohaibani M, Al-Massarani SM, Ahmad A, et al. Beetroot (Beta vulgaris L.) extract ameliorates gentamicin-induced nephrotoxicity associated oxidative stress, inflammation, and apoptosis in rodent model. Mediators of Inflamm. 2014;2014:983952. http:// dx.doi.org/10.1155/2014/983952

PMid:25400335

27. Agarwal M, Srivastava VK, Saxena KK, Kumar A. Hepatoprotective activity of Beta vulgaris against $\mathrm{CCl}_{4}$-induced hepatic injury in rats. Fitoterapia. 2006;7(2):91-3. http://dx.doi. org/10.1016/j.fitote.2005.11.004

PMid:16376022 